\title{
ARTICLES
}

\section{Let Him Hold You Spiritual and Social Support in a Catholic Convent Infirmary}

\author{
Anna I. Corwin \\ Department of Anthropology \\ University of Californa Los Angeles
}

\begin{abstract}
American Catholic nuns have been found to age more 'successfully' than their lay counterparts, living longer, healthier, and happier lives. Two of the key factors contributing to the nuns' physical and mental wellbeing are the spiritual support they experience from the divine and the social support they provide for and receive from each other in the convent. I argue that by integrating the divine into their everyday interactions, the nuns engage in phenomenological meaning-making process through which mundane care interactions are rendered sacred. This communicative process, I argue, contributes to the nuns' overall wellbeing by providing an enriched form of care and support, thereby enhancing their end-of-life experience.
\end{abstract}

Keywords: Aging, Care, Prayer, Wellbeing, social support, Catholicism

\section{INTRODUCTION}

My third summer as a researcher in the infirmary wing of the Franciscan Sisters of the Heart Convent, I found myself sitting in Sr. Theresa's small room ${ }^{1}$. Sr. Theresa was in her mid-eighties and had lived in the infirmary for two years due to trouble walking and her limited ability to navigate the convent hallways and to negotiate physical tasks of daily living. We spent the afternoon as we'd spent many afternoons together. She spoke to me about the spiritual books she' $\mathrm{d}$ been reading and she talked about the spiritual connection she felt with God in nature. She spoke for quite a while, stopping often to laugh with reverence about the mystery and beauty of the world. After a pause, she began a story about speaking to Jesus:

The other night I was sitting here, and I said, "You know what Jesus? I feel like an old married woman and you're an old married man." And I said, "We're sitting in a swing on a porch. That's where I see us right now." And I said, "And I get the idea that you're thirsty," I said, "So, I'm going in to get you some lemonade." So I come out with a big glass of lemonade, and He nearly drinks all that then He looks at me and smiles and said, "How did you know I was thirsty?" And I said, "Cause I love you."
At the end of this story, Sr. Theresa erupted into a bout of contagious laughter that punctuated all of her conversations. She ended the story with the statement: "so that's my spirituality." I asked her how often she talks like this to Jesus, and she exclaimed, nearly exasperated by the naïveté of my question: "OH! All day, all day! We're inseparable."

Although Sr. Theresa was a joyfully unique personality in the convent - certainly the only person who mentioned sharing lemonade with Jesus - her relationship with the divine is nonetheless representative of the relationship many of the nuns have with the divine. A majority of the nuns in the Franciscan Sisters of the Heart describe experiencing the divine as an enduring presence in their everyday lives. They engage $\mathrm{Him}^{2}$ in conversation, watch television with Him, or hold His hand as they walk the convent grounds. They experience Him variously as a spouse, a companion, a spiritual presence, and a caretaker. For almost all of the nuns in the convent, the divine is an enduring presence who accompanies them in every activity and shapes their experience of the world.

In this article, I examine the caretaking interactions between the nuns in the infirmary wing of the Franciscan 
Sisters of the Heart convent to show what social and linguistic tools elderly nuns use to integrate the divine into their everyday interactions and how these interactions render all health-care interactions in the infirmary sacred. I argue that these care interactions impact the nuns' wellbeing in three major ways: First, the care interactions include blessings through which the caregivers offer both social and spiritual support; second, the nuns invoke the divine in conversational care interactions in such a way that Christ emerges as an engaged caretaker; finally, the nuns summon the divine into their lives by living the powerful trope of "being God" for each other and receiving others as the divine. These three practices, I argue, provide spiritual and social support that impacts the nuns' quality of life.

\section{The Sisters OF THE HEART}

The Franciscan Sisters of the Heart convent is a Catholic convent in the Midwestern United States that is home to more than 200 nuns. Approximately 100 of them, having worked as teachers and missionaries outside the convent walls, have returned to the convent to retire. They now live in the convent full time where they have access to nursing care. This article draws on data collected in the convent over ten months beginning in 2008. During the summers of 2008,2009, and 2010, I lived in the convent with the nuns for a period of one to two months each summer. For a period of five months in the winter and spring of 2011, I lived in an apartment near the convent and spent my days in the convent with the nuns. The corpus of data includes over 100 hours of recordings of naturally occurring events in the convent such as meals, social events, and care interactions. In addition, I conducted over thirty personcentered interviews (Levy and Hollan 1998). Analysis in this article focuses on a corpus of over twenty hours of care interactions between a retired caregiver and the recipients of her care, many of whom are her contemporaries, recorded in the convent infirmary in 2011.

\section{BACKGROUND}

In her article Communication and the Institutionalized Elderly, Karen Grainger describes the communicative exchanges between elderly individuals and their institutional caregivers. Grainger describes an isolated communicative landscape in which individuals are often left alone (1995). When they are communicatively engaged, their concerns are often demeaned or ignored. This bleak communicative landscape with few "confirmative and stimulating adult-to-adult encounters" is unfortunately common in end-of-life care and has been found to negatively affect elderly patients' cognitive function
(Williams 2011:9). Grainger suggests that the "most important move" for the future of institutional care for the elderly, would be "for elderly long-term care to take place in an environment in which the status of caring (vs. curing) is elevated to the level of a valued occupation and skill" (1995: 433). The convent employs a palliative model of care, with the goal of providing ongoing holistic care to all of the sisters, attending to not only medical needs, but also the emotional, spiritual, and social concerns of each of the individuals in the community. The elderly Catholic nuns examined in this article experience the type of care Grainger envision as ideal, elevating "caring" over "curing," prioritizing and implementing multiple modes of care at the end of life.

Epidemiologists have identified American Catholic nuns as a group that lives longer healthier lives than their lay counterparts, experiencing less anxiety, pain, and depression at the end of life (Butler and Snowdon 1996, Snowdon 2001). Quality of life questionnaires (designed by Cohen et. al 1997) I administered in this convent confirmed that, like their peers, the Franciscan Sisters of the Heart report less anxiety and psychological distress and greater feelings of social support than their peers. In addition to education, nutrition, physical activity, and optimistic outlook, spiritual and social support have been found to significantly contribute to the nuns' wellbeing. It has been found that there is a statistical connection between social support, including social interaction (Cacioppo and Patrick 2008), receiving the help of others (Maton 1989, Reichstadt et al. 2006) and the act of caring (Corwin 2005) foster physical and mental health in elderly individuals. However, there has been little previous exploration of how these interactions unfold in situ.

In addition, an increasing number of studies suggest that religious practices including prayer, meditation, and participation in religious services aid the mental and physical health of the practitioner, promoting physical well-being and protecting against depression (Koenig et al. 1997, Koenig 1999, Newberg 2006, Strawbridge et al. 1997). Through meditation, for example, Tibetan monks are able to neurologically train their brains to reinforce "positive feelings and well-being" (Newberg 2006: 187). In the convent, prayer organizes Catholic nuns' daily lives, represents and encodes moral and ideological tropes, and impacts the nuns' subjective and embodied experiences in the world (Corwin 2012, Lester 2005). Pevey et al. (2008) argue that religion provides a supportive relationship with a divine being (2008: 55). Although these studies have shown a quantitative connection between spirituality and wellbeing, this study is one of the first to document 
spiritual and social support interactions as they unfold in ethnographic context.

In this article, I examine caretaking interactions in the convent infirmary to argue that: First, for the nuns, these two processes of social support and spiritual support are interactionally intertwined such that they jointly unfold in caretaking interactions. Second, I show how spiritual support is communicatively established in caretaking interactions. I find that three activities within the caretaking activities: blessings, summoning the divine, and the trope of "being God," contribute directly to the nuns' spiritual and social support.

I argue that through these processes, in which the nuns invoke the divine in everyday activities, the nuns engage in a phenomenological reality-shaping process outlined by Alfred Schutz in his article "On Multiple Realities" (1945). Schutz argued that individuals pass through a number of experiential domains throughout the course of everyday life, each of which is associated with a particular cognitive style and a particular "accent of reality." Each of these "accents of reality" or particular ways of being in the world is contained within its own "finite province of meaning" that "would appear as merely fictitious, inconsistent and incompatible" (Schutz 1945: 553) in another context. I follow Schutz's model to argue that this process contributes to the nuns' overall wellbeing at the end of life.

\section{Care in the Convent}

Care in the convent provides a contrast to that of most institutional care facilities. First, and perhaps most significantly, the nuns chose to enter this institution long before they were in need of care. The nuns joined the convent as sixteen- to twenty-year-old girls, choosing to dedicate their lives to service to the Church as teachers, missionaries, and nurses. They have lived and worked as part of this community for all of their adult lives. The majority of the nuns live in small convents near Catholic schools or parishes where they work and return to the central convent or motherhouse for summer retreats and meetings. By the time they enter the convent infirmary, they feel as if they are "coming home." Sr. Carline, for example, spoke to me about her experience coming "home" to the motherhouse when she retired. She describes her return home as an experience of "coming full circle":

I came home here four years ago. And in the dining room we have these round tables, you know just sit wherever, and so I had no trouble adjusting when I came, retired, no trouble whatever, I mean it was like I started here full circle and I come here all the time you know for any kind of celebration full circle and I'm coming home. And so I've known these people for sixty-seven years, you know, so it's not like I'm coming into a nursing home of strangers, these are friends.

In many ways, this return "home" is the opposite of the move experienced by most lay individuals who must give up their homes when they enter assisted living or nursing homes. Although the nuns may not know the individuals who live with them in the infirmary, the infirmary is part of an institution they've been part of for most of their lives, and they share a sense of community, history, and common life experience. Sr. Rita, who worked as a pastoral care minister in a hospital before she retired reflected on the convent infirmary. She describes it as a unique setting that maintains a deep sense of community, which she contrasts with a hospital or nursing home setting:

I think that maybe in the hospital, nursing home, [the employees] don't want to be attached, in the sense that it means that when that patient dies or goes, (you know) won't be seeing (her) again, but here we have a continuity because this is our Mother House, this is our home, this is home. So when you come here, we're all going to be here.

Because the nuns take their peers in the infirmary to be an extended family, and they are cared for by people with whom they have a shared history, the nuns do not experience the same level of loneliness, isolation, or abandonment that many elderly individuals in long-term care facilities endure. In addition, since they have taken the vow of poverty, almost all of the income they generate throughout their working lives goes directly to the convent. The convent administrators manage the group finances and plan for the housing and medical care for all of the nuns. Although many convents are struggling financially to manage the end-of-life care of their members, none of the members has the sole responsibility of financing her individual retirement and end-of-life care.

The nuns, however, do not always find the transition into retirement to be easy. In this way, they share a few significant similarities with lay individual entering a longterm careinstitution. The majority of thenuns havenot lived in the convent since they were novices. They have worked their whole lives, often much more than 40 hour weeks, and are deeply involved in the local communities in which they work and with the small usually multi-generational convent in which they live. These women rarely choose 
on their own to leave these busy lives in which they are important contributors to local communities, often in positions of authority as teachers or community organizers to come to a convent infirmary. Most of the nuns work until physical or mental deterioration makes it impossible for them to continue. Even then, many of the sisters retire to the convent only after they are asked, or sometimes required, by the convent authorities. When they do return to the convent, the nuns, again like their lay counterparts, must give up many of the freedoms and responsibilities they held outside the convent. In the small convents where they work, the nuns cooked, cleaned, and generally were in charge of themselves and their small community. In the motherhouse, they are served three meals a day in a cafeteria or in their rooms in the infirmary. They can travel the five miles into town only when someone with a car is scheduled or persuaded to bring them. If they are not mobile, they rely on nurses or aides to clean their rooms, and to clothe and to bathe them. For women who have spent their lives caring for others, and striving to ask for as little as possible, the transition from an active, working life, to a retirement in which they are dependent on others, can be very difficult.

When the nuns retire to the convent, they live in one of three types of living quarters, which range from independent living, moderately assisted living, and fulltime care in the infirmary. Active and working sisters, including newly retired sisters who can live independently, live in rooms with shared dormitory-like bathrooms and, in some cases, shared kitchens. Even the nuns who are most independent adjust to reduced independence and self-sufficiency. They are no longer responsible for their own cooking or transportation, and now must fit into an institutional schedule of community prayers, meals, and daily activities and duties. The nuns who are primarily self-sufficient and require minimal physical assistance live in a three-floor wing of the convent that has been converted to offer private bathrooms that are handicapped accessible as well as easy access to the dining room and nursing station in the infirmary. The infirmary, which has full-time nursing care for those who need it, is a three-floor wing of the convent, housing 45 to 80 individuals at a time.

Nuns in the infirmary have private rooms with televisions connected to a closed-circuit channel that broadcasts community activities from the chapel, including daily prayer and mass. There is a nurses' station on each floor as well as a dining room. Nurses and aides, employed from the local community, care for the nuns' daily personal and medical needs. In addition, each floor has a pastoral care minister, a nun in the community who cares for the nuns' spiritual needs - making sure she is able to take communion, access spiritual books or materials, receive spiritual direction or confession if she desires. The pastoral care minister also helps with personal communication, opening and answering mail, and she organized group activities, such as special prayer meetings, in the infirmary. The convent also employs a wellness director who is in charge of physical activity, keeping the elderly nuns active, and assisting with any physical therapy.

The care interactions in the infirmary are organized around meeting the physical, social, and spiritual needs of the elderly nuns. They do not receive medical care in the convent, and must be driven to doctor's appointments. There are a number of retired sisters who volunteer to drive those who cannot drive to medical appointments. There is a large network of volunteers among the retired sisters, living both in the infirmary, and in the larger convent, who visit the sisters in the infirmary, pray for them, and who visit those who are in the hospital for surgery or other major medical treatments.

The majority of the nuns in the infirmary are there for chronic conditions, most often those associated with old age and will therefore live out the rest of their lives in the convent. The majority of the sisters do not expect to be "cured" or "healed" of the particular chronic conditions from which they suffer, however they do strive for physical and mental wellbeing, with as little pain and physical/ mental suffering as possible. The concept of healing is rarely invoked in the infirmary. Instead, the nuns see themselves engaged in an ongoing process in which they strive for wellbeing. This wellbeing includes acceptance of whatever may come, including the unpleasant experience of illness. Sr. Carline, who had an advanced form of bladder cancer, spoke about this process of acceptance and surrender:

I know that physical healing isn't gonna last forever; it doesn't last forever for anybody, but for me it's more imminent and I know it's not gonna [last]. ... The main kind of healing is spiritual healing; you know that your whole body can accept whatever is coming in your life. You know if somebody says 'do you want to die', no I don't want to die, I mean you know it's not that I'm craving to die although sometimes, sometimes when you're feeling kind of sick or you know you don't feel good you thought oh maybe that's not gonna be so bad, you know? But it's not that I'm uh you know sitting here waiting to die but I'm gonna take when it comes, you know, I want to be ready to hand it over, to surrender when that 
time comes.

Sr. Carline contrasts physical healing, which she describes as temporally limited, with "spiritual healing" which she describes as a "whole body" acceptance of "what is coming", meaning, in this case, her death. Sr. Carline's model of healing, which is consistent with the model I found in the convent as a whole, exemplifies the nuns' values of serenity and acceptance of the future, which they understand to be God's path for them. Unlike many Christians, the nuns do not rely on the divine to intercede in their physical healing. Although the nuns believe the divine has the power to intercede in the material world, they focus their petitions to the divine on requests for endurance and for spiritual comfort. Instead of requesting the divine to change the material world, to heal them, the nuns rely on interactions with the divine for sense-making and for an enduring sense of wellbeing. Sr. Carline, for example, understands that she has a terminal illness and accepts her oncologist's prognosis. She turns to the divine to help her develop a sense of peace and acceptance, what she calls "spiritual healing."

The nuns, like many elderly individuals, embody healing trajectories that are not strictly bounded in time. Their healing trajectories are neither restricted to physical transformations, nor are they restricted by the temporal bounds of a healing event. The model presented in the convent by nuns like Sr. Carline is one in which healing is not contained by a bounded medical diagnosis. This model fits well with Csordas and Kleinman's argument that healing is not contained within therapeutic events, but rather "spills" into the larger temporal framework of everyday life (1996) ${ }^{3}$. The nuns do not focus exclusively on physical healing, which is a unidirectional process in which healing events (such as surgeries or therapeutic treatments) are conceptually contained as either "successful" or "unsuccessful" events. Instead, the nuns see themselves as involved in an ongoing day-to-day process in which they strive for spiritual as well as physical wellbeing. This process continues throughout the life course, beginning when the nuns join the convent to begin their spiritual journal as novices (see also Lester 2005).

In the next section, I will show how spiritual healing is constructed in the care interactions between the elderly nuns in the convent infirmary.

\section{CARETAKING}

Sister Irma is an 83-year-old nun, who worked in various positions throughout her life as a teacher and community leader before she retired to the motherhouse. Now that she is retired, she spends part of the week providing foot massages to elderly sisters in the infirmary. Sr. Irma spends each Monday and Tuesday afternoon massaging the feet of the elderly sisters in the infirmary and providing acupressure treatment. She goes into each room and offers massage. When she is invited in, Sr. Irma removes the shoes and socks from the sisters' feet; she encourages them to relax; and she massages their feet as they recline in an easy chair or on the bed. In these interactions, Sr. Irma sees herself as contributing to her peers' medical care. She is working to generate circulation in the feet of elderly sisters who are no longer mobile. This form of physical care is essential for the protection of the elderly sisters' limbs, the importance of which the nuns are acutely aware. During the final year I was in the convent, a 99-year-old sister had her leg amputated due to lack of circulation in her limbs.

As Sr. Irma contributes to the nuns' physical wellbeing, she simultaneously engages in spiritual care-taking. Like many of her peers, when Sr. Irma engages with the sisters in the infirmary, she invokes the divine as an engaged interlocutor and caretaker. This is achieved in three ways: First, through prayer which occurs here primarily in the form of blessings, second, by summoning God as a participant in ongoing interactions, and finally through embodying the divine for others and experiencing others as the divine.

\section{Prayer}

The most common form of prayer in care interactions in the convent is blessings. Blessings are an "invocation of divine favor" on an activity or individual (Bruder 1998:466). As Sr. Irma blesses the sisters, she calls on the divine to care for them, to offer them peace, or to be with them as an enduring presence.

The following excerpt represents a typical blessing in the convent:

\section{Example 1: Blessing}

SI: Sister Irma

SS: Sister Suzie

SI: There ya' go. You ready for your blessing? SS: Mm Hmm

SI: Okay. May the Lord bless you and keep you. May He give you courage to live each day knowing He is with you. Amen.

Blessings occur in the subjunctive mood (Bruder 1998: 470). In providing a blessing, the speaker is speaking 
directly to the divine, petitioning Him to provide a favor to the speakers. In this way, blessings can be seen as requests to a third party not previously addressed in the interaction.

I suggest that blessings actively shift conversation from a typical dyadic arrangement in which the two individuals in the room are speaking to each other (represented below) to a tripartite interaction. Before the blessing, the two participants are engaged with each other, each as a ratified speaker and listener (Goffman 1979).

\section{Interlocutor $1 \longleftrightarrow$ Interlocutor 2}

Figure 1: Dyadic Interaction

When a blessing is introduced, the participant arrangement of the interaction moves from a dyadic arrangement to a tripartite or multiparty arrangement in which the divine is addressed as a participant (see also Ochs and Capps 2001). As the nuns ask the divine for a blessing, pronouncing an utterance such as "May the Lord bless you," in which they ask the divine to intercede in the room or in the world, the participants involved in the interaction now include both the two original interlocutors as well as the divine:

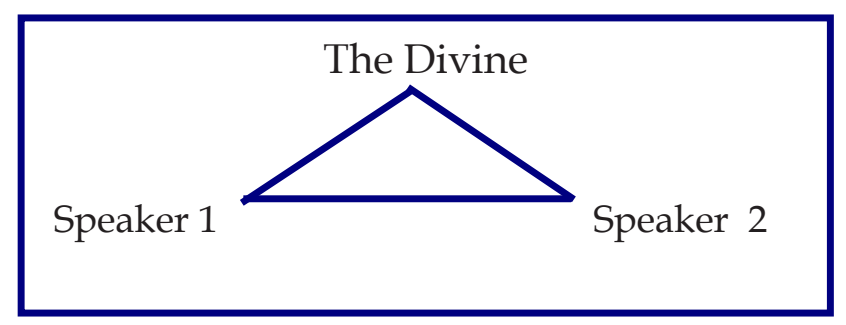

Figure2: Multiparty Interaction Including the Divine

In this way, the divine is brought into the room as a relevant participant in the interaction.

As Sr. Irma blesses Sr. Suzie in the exchange above, saying "May the Lord bless you and keep you", she is calling the divine into the room as an interlocutor, asking Him to hear her request for Sr. Suzie, and to intervene as He sees fit, presumably blessing Sr. Suzie, keeping her, and giving her the courage and peace of His presence. The blessing achieves three actions. First, it is a way for
Sr. Irma to communicate to Sr. Suzie that she wishes her peace, courage, and an awareness of the loving presence of the divine in her life. In this capacity, the blessing is a form of peer social support through which Sr. Irma can offer intimate support and hope for Sr. Suzie. Second, it is a direct request for the divine to intervene in the world by providing the requested blessing. Finally, the blessing is a way for Sr. Irma to bring the divine into the room as an engaged interlocutor, as a being whose presence becomes engaged in the activity. Through the blessing interaction, the divine becomes an addressed interlocutor, engaged in the communicative activity at hand.

\section{Summoning God}

Sr. Irma also brings the divine into the room by calling on Him directly as an engaged participant in the interaction. Sr. Irma often reminds people to talk to Jesus. As she leaves a room, she frequently says, "Jesus said to tell you that he loves you." While she is in the infirmary, she regularly calls on Him as an embodied participant in the interactions.

In following example, Sr. Irma massages Sr. Mary Augusta's feet. Sr. Mary Augusta is in her late 80s. She had just explained to Sr. Irma that she is suffering from a "bad heart" and that she "won't last much longer." She has been having bouts of tachycardia for the past few weeks and has had little energy. Sr. Irma had encouraged her to relax while she received the massage, and Sr. Mary Augusta had complained that she couldn't. As Sr. Irma encouraged Sr. Mary Augusta to relax, she invokes the divine. In the example, Sr. Irma encourages Sr. Mary Augusta to call on Jesus to comfort her and thereby to cultivate an embodied relationship with Jesus that might benefit her physically and psychologically.

\section{Example 2: Let Him Hold You \\ S.Irma - Sister Irma \\ S.MA - Sister Mary Augusta}

S.Irma: And know that the Lord does love you.

S.MA: I knew that.

S.Irma: And He wants you to relax. [And,]

S.MA:

S.Irma: And let Him hold you.

[I know]

S.MA: I have a hard time relaxing.

S.Irma: Let Jesus hold you, and don't squirm in His arms.

Srs. Irma and Mary Augusta are embedded in an institutional framework in which the divine is understood to be a constant embodied presence. Sr. Mary Augusta, like Sr. Theresa, describes Jesus as a constant companion. She describes watching television with Him each evening, His 
hand holding hers. She talks about engaging in physical embraces with Him (a huge hug, as she describes it) each time she passes a crucifix in the convent.

Sr. Irma's directive, imploring Sr. Mary Augusta to let Jesus hold her in his arms therefore emerges in a framework in which Jesus exists to them, if not necessarily visibly, as nonetheless real and embodied. Sr. Irma's directive "let Jesus hold you, and don't squirm in His arms" is not just a metaphor. It is an embodied directive that emerges in a context in which touching Jesus and being held by Him is common and, moreover, possible. In this interaction, Sr. Irma instructs Sr. Mary Augusta to call the divine into the room and to rely on Him to help quell her anxiety.

In addition to encouraging Sr. Mary Augusta to summon the divine, Sr. Irma is also engaging in peer socialization, communicating what she sees as appropriate and expected behavior for a Catholic nun in their community. By suggesting that Sr. Mary Augusta engage with Jesus in a physical way, allowing Him to care for her, Sr. Irma is suggesting that she experience the embodied states the nuns associate with a divine embrace such as peace, love, support, and calm. She redirects her complaints, subtly suggesting that the complaints may not be appropriate. In doing this, Sr. Irma communicates to Sr. Mary Augusta not only that it is expected for her to turn to God in her times of need, but also that that the divine is the interlocutor and embodied caretaker who can offer her the most support and assistance with her physical and psychological ailments.

\section{Being God}

Finally, the nuns also bring the divine into their everyday interactions through the trope of "being God" for each other. As Sister Irma explained in an interview:

To be there for other people is my greatest prayer. I pray with my community and with other people, through who I am and what I do. So communicating with them, the God in them, the God in me in a peaceful and gentle and just a way of graciously being.

For the nuns, embodying the divine means two things: First that they will model Christ's behavior as closely as they can, serving others with humility and compassion. Second, it means treating others as they would treat the divine. As one nun explained to me, this means communicating with others as if she or he is Christ Himself.

In a talk on prayer that Sr. Irma gave to a group of the retired nuns, she made explicit the metaphor of "being Jesus" for others. In this lecture, she argues that in order to follow Jesus' command to "Go out and be the light of the world" (line 1), the nuns should embody the physical presence of the divine (line 3) through everyday acts of prayer and compassion. Here, she describes this in detail:

Example 3: Be the Light of the World

S.Irma - Sister Irma

S.Lup - Sister Lupita

1 S.Irma: If Jesus says, "Go out and be the light of the world,"

2 We are His presence.

3 The physical presence of Jesus among others,

4 and so, it is our vocation as Christians to be that in some way.

5 Whether it's just praying for people,

6 or listening to people,

7 or serving people in any way,

8 but when we're in need,

9 we have to be gracious

10 to allow others to do that for us.

11 To share our pains,

12 to share our needs,

13 to let others listen to us,

14 so it's a two-way street.

15 If I am Jesus for Sr. Lupita today,

16 tomorrow I may need Sr. Lupita to be Jesus for me.

$17 \quad$ Would you do that Lupita?

18 All: ((laughter from sisters))

19S.Lup: ((Sr. Lupita nods))

20 S.Irma: She would do that.

$21 \quad$ Alright.

At the end of the passage, Sr. Irma gives the example of "being Jesus" for someone. She suggests that while she might "be Jesus" for Sr. Lupita one day, Sr. Lupita will reciprocate by embodying the divine for Sr. Irma another day (lines 15 and 16). By embodying the divine, Sr. Irma suggests the nuns will continue God's work on earth with Him and for Him by spreading love, compassion, and by serving others. The nuns see themselves fulfilling this goal through everyday activities both spiritual and mundane. For example, many of the nuns serve others by bringing them feeding them or helping them bathe. Others might fulfill the quotidian tasks necessary to keep the convent running, for example, answering the phones or cleaning the bathroom.

One of the ways that Sister Irma strives to communicate the "God in [her]" with the "God in them," as she put it, is through the foot massages she gives. As she sits by the elderly sisters' feet, and takes them into her hands, she, and the other sisters in the community are consistently made 


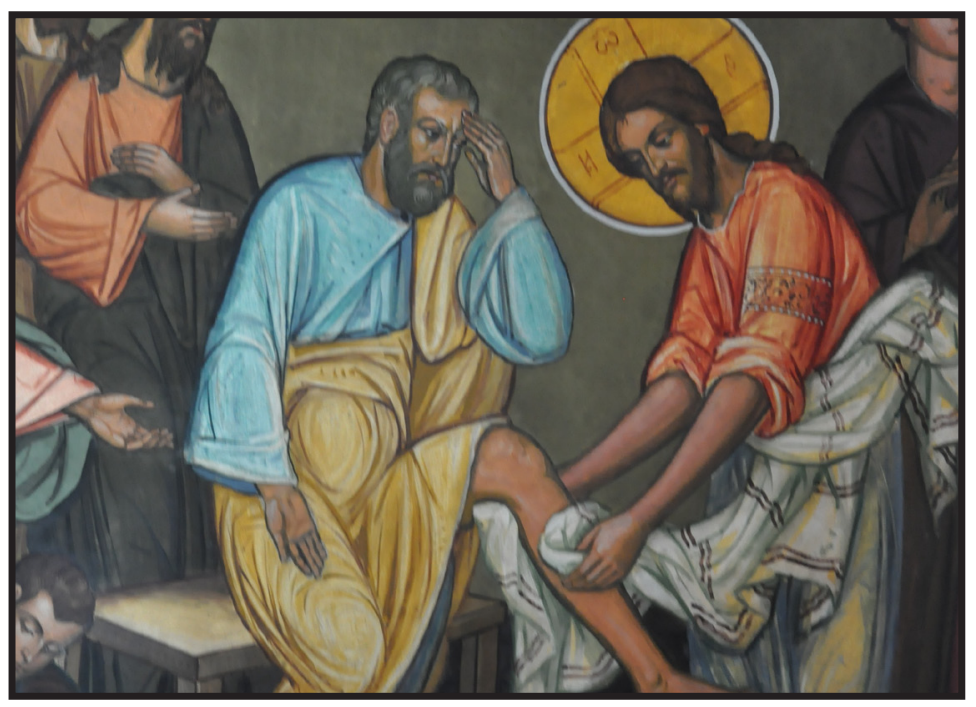

Figure 3: Images of Jesus with the disciples

aware of the story of Jesus washing the disciples' feet. In embodying this metaphor, Sister Irma superimposes the trope of Jesus' humility and devotion on top of her own interactions with her community of elderly peers.

The nuns' awareness that Sr. Irma is indexing the interaction between Jesus and the disciples is made salient through the frequent references they make to letting $\mathrm{Sr}$. Irma "serve" them. Sr. Irma also sometimes jokes about the engagement and its similarity to Jesus' washing of the disciples' feet. In the example below, Sr. Irma teases another nun about the work involved in removing and replacing her stockings, saying that Jesus never had to wrestle with the disciples' stockings:

Example 4: In Jesus' Time

S.Irma - Sister Irma

S.Irma: I wonder-

Jesus didn't have to do this, did He?

'Cause they didn't wear socks then.

(laughter)

You just hadda put the slippers back on 'em. That's okay, I won't charge you extra.

Through this practice in which she serves her fellow nuns with humility as Christ served the disciples in the Bible, Sr. Irma is performing both a symbolic, metaphorical act and a ritual act. Like all embodied practices, this practice "confirms the reality - not just the symbolic idea - of a ritual act" (McGuire 2009: 7). As the ritual act of being Christ is

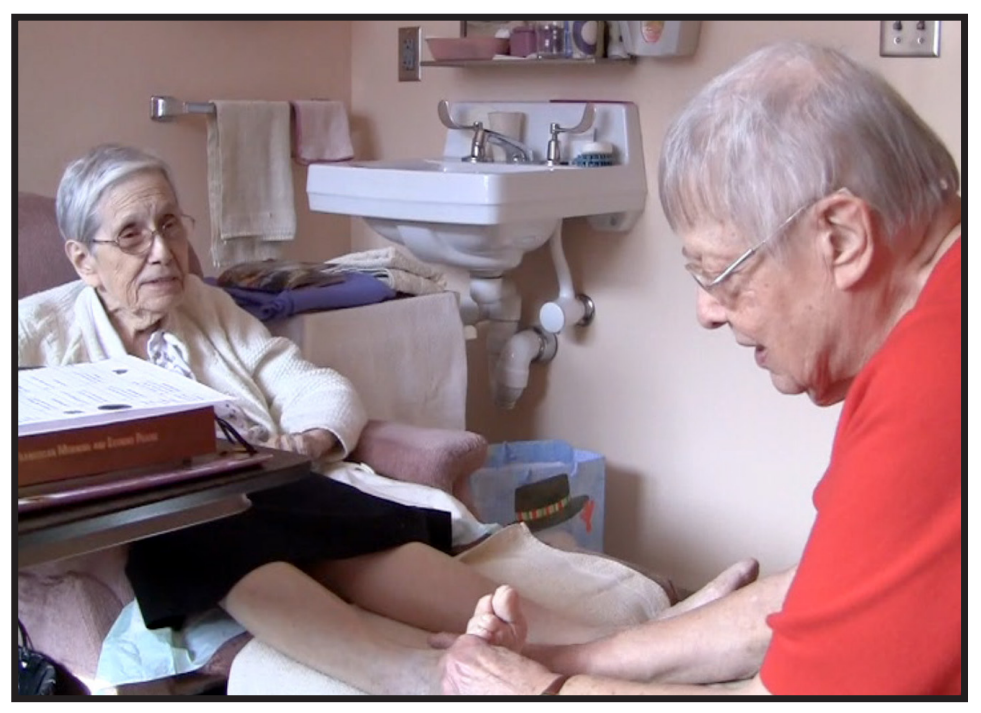

Figure 4: Image of Sr. Irma massaging her peer's feet

overlaid on a mundane interaction promoting circulation, Sr. Irma constitutes a sacred reality in which she, as a divine servant, is humbly serving her peers in the infirmary as Christ served His disciples. The act of massaging the nuns' feet brings the divine into the nuns' tangible daily lives. My corpus of interview data has shown that interactions like these produce a calming, loving experience for the elderly nuns as they receive Sr. Irma's service. In this way, Sr. Irma's embodied ritual produces tangible, subjective and social effects in the world.

\section{CONCLUSION}

Through everyday linguistic and embodied practices, Ihave argued that the nuns engage the divine in three primary ways (1) through prayer, (2) by summoning the divine's presence into the room and (3) through the powerful trope of "being God" to each other. Through these processes, I argue that the nuns constitute a particular reality, or, in Schutz's terms, a "finite province of meaning" in which the divine exists in every interaction as a caretaker, in which other persons are no longer just human subjects, but also representatives and embodiments of the divine. Through these interactions, the nuns create for one another and for themselves a reality in which the divine tangibly exists to them. This "province of meaning" that shapes their reality is distinct from a strictly secular or medical world, and yet is thoroughly integrated into it.

As the nuns constitute the divine as an embodied 
participant present in their lives, the social support the nuns receive from each other is dynamically integrated with the social and spiritual support they exchange with the divine. As they receive care and support from their human peers, they also experience the divine healing presence of God. The nuns describe experiencing the divine as a presence that accompanies them throughout the day. When they hold His hand or speak to Him, they describe experiencing various embodied states including joy, peace, calm, and love. As the nuns engage with the divine, the phenomenological reality they constitute, in which they are enveloped in peace and love, impacts their psycho-emotional wellbeing. They describe feeling loved and calmed.

These embodied engagements in which the divine becomes integrated into the nuns' everyday interactions - through prayer, through an embodied presence, and through the nuns' very bodies - shape the nuns' experience of care and wellbeing. As the nuns superimpose this sacred reality onto everyday physical/medical care interactions, the nuns' wellbeing, as well as their overall health trajectories are impacted

These embodied rituals are central to the nuns' enduring wellbeing at the end of life. As the nuns imbue everyday care-taking interactions with embodied engagements with the divine, medical interactions take on sacred meaning, and the nuns experience care, and comfort, and an enduring sacred presence. They are not engaged in a temporal healing trajectory that may or may not be successful and they thus avoid encountering failed healing events. Instead, they are engaged in an ongoing (life-long) process of wellbeing, which shapes all encounters, whether medical or mundane, as sacred encounters with the divine.

\section{Acknowledgments}

Research for this article was supported by the National Science Foundation [\#1026025]. I am grateful for the ongoing support and encouragement of Elinor Ochs, Alessandro Duranti, and Jason Throop. An earlier version of this paper was presented at the 2011 American Anthropological Association Annual Meetings. Earlier drafts of this article benefitted from detailed comments and insights from Keziah Conrad, Hanna Garth, Jennifer Guzmán, and Jessica Hardin. Any errors or oversights remain my own.

\section{Notes}

${ }^{1}$ All names, including the name of the convent, are pseudonyms.

${ }^{2}$ A note on style: the capitalization of pronouns referring to the divine is consistent with the nuns' usage.
${ }^{3}$ This concept of healing as temporally unbounded has been taken up by recent authors working on chronicity. For example, Smith-Morris argues that the acute/chronic dichotomy is not representative and can be problematic (Smith-Morris 2010).

${ }^{4}$ Of course, if the blessing occurs in a group setting with overhearers the blessing would be a multiparty interaction.

\section{REFERENCES}

Barsalou, Lawrence W., Barbey, Aron K., Simmons, W. Kyle, and Santos, Ava

2005 Embodiment in Religious Knowledge. Journal of Cognition and Culture 5:14-57.

Bruder, Kurt A.

1998 A Pragmatics for Human Relationship with the Divine: An Examination of the Monastic Blessing Sequence. Journal of Pragmatics 29:463-491.

Butler, Steven M., and David A. Snowdon

1996 Trends in Mortality in Older Women: Findings From the Nun Study. Journal of Gerontology: Social Sciences 51B (4):S201-S208.

Cacioppo, John T, and William Patrick

2008 Loneliness: Human Nature and the Need for Social Connection. New York: W.W. Norton and Company Inc.

Cohen, Robin S., Balfour M Mount, Eduardo Bruera, Marcel

Provost, Jocelyn Rowe, Kevin Tong

1997 Validity of the McGill Quality of Life Questionnaire in the Palliative Care Setting: a Multi-centre Canadian Study Demonstrating the Importance of the Existential Domain. Palliative Medicine 11(3):17-37.

Corwin, Anna I.

2012 Changing God, Changing Bodies: The Impact of New Prayer Practices on Elderly Catholic Nuns' Embodied Experience. Ethos 40(4): 359-389.

Corwin, Jennifer Haskin

2005 The Fear of Death and the Fear of Dying: Possible Barriers to Altruistic Behavior. Masters Thesis, Department of Sociology, Anthropology, and Criminology, Eastern Michigan University.

Csordas, Thomas, and Arthur Kleinman

1996 The Therapeutic Process. In Medical Anthropology:

Contemporary Theory and Method Revised Edition. C.F.

Sargent and T.M. Johnson, eds. Pp. 3-20. Westport, CT and London: Praeger.

Goffman, Erving

1979 Footing. Semiotica 25(1/2):1-29. 
Grainger, Karen

1995 Communication and the Institutionalized Elderly.

In Handbook of Communication and Aging Research. J.

Nussbaum and J. Coupland, eds. Pp. 417-436. New Jersey:

Lawrence Erlbaum Associates.

Koenig, Harold G., et al.

1997 Attendance at Religious Services, Interleukin-6, and

Other Biological Parameters of Immune Function in Older

Adults. The International Journal of Psychiatry in Medicine 27(3):233-50.

Koenig, Harold G.

1999 The Healing Power of Faith: Science Explores

Medicine's Last Great Frontier. New York: Simon \&

Schuster.

Lester, Rebecca J.

2005 Jesus in Our Wombs: Embodying Modernity in a

Mexican Convent. Berkeley, CA: University of California Press.

Levy, Robert, and Douglas Hollan

1998 Person-Centered Interviewing and Observation in

Anthropology. In Handbook of Methods in Cultural

Anthropology. H.R. Bernard, ed. Pp. 333-364. Walnut

Creek, CA: Altamira Press.

Maton, Kenneth I.

1989 The Stress-Buffering Role of Spiritual Support: CrossSectional and Prospective Investigation. Journal for the

Scientific Study of Religion 28(3):310-23.

McGuire, Meredith B.

2003 Why Bodies Matter: A Sociological Reflection on Spirituality and Materiality. Spiritus: A Journal of Christian Spirituality 3(1):1-18.

Newberg, Andrew

2006 Why We Believe What We Believe: Uncovering Our

Biological Need for Meaning, Spirituality, and Truth. New

York: Free Press.

Ochs, Elinor, and Lisa Capps

2001 Living Narrative: Creating Lives in Everyday

Storytelling. Cambridge, MA: Harvard University Press.

Pevey, Carolyn F., Thomas J. Jones, and Annice Yarber

2008 How Religion Comforts the Dying: A Qualitative

Inquiry. Omega: Journal of Death and Dying 58(1):41-59.

Reichstadt, Jennifer, Colin Depp, Lawrence Palinkas, David

Folsom, and Dililp Jeste

2006 Building Blocks of Successful Aging: A Focus

Group Study of Older Adults' Perceived Contributors to

Successful Aging. American Journal of Geriatric Psychiatry 15(3):194-201.

Schutz, Alfred

1945 On Multiple Realities. Philosophy and

Phenomenological Research, 5(4):533-576.
Seligman, Rebecca

2010 The Unmaking and Making of Self: Embodied

Suffering and Mind-Body Healing in Brazilian Candomblé. Ethos 38(3):297-320.

Smith-Morris, Carolyn

2010 The Chronicity of Life. In Chronic Conditions, Fluid

States. L. Manderson and C. Smith-Morris, eds. Pp. 21-37.

New Brunswick, New Jersey: Rutgers University Press.

Snowdon, David

2001 Aging with Grace. New York: Bantam Books.

Strawbridge, William, Cohen, Richard D., Shema, Sarah J.,

Kaplan, George A

1997 Frequent Attendance at Religious Services and Mortality over 28 Years. American Journal of Public Health 87(6):95761.

Williams, Kristine

2011 Elderspeak in Institutional Care for Older Adults. In Communication in Elderly Care: Cross-Cultural Perspectives. P. Backhaus, ed. Pp. 1-19. London: Continuum. 